\title{
Critical evaluation of techniques to detect and measure cell death - study in a model of UV radiation of the leukaemic cell line HL60
}

\author{
Marina Leite, Margarida Quinta-Costa, \\ Pedro Simas Leite and José Eduardo Guimarães * \\ IPATIMUP, Instituto de Patologia e Imunologia \\ Molecular da Universidade do Porto, Portugal \\ Received 23 August 1999 \\ Accepted 16 November 1999
}

The reliability of eight distinct methods (Giemsa staining, trypan blue exclusion, acridine orange/ethidium bromide (AO/EB) double staining for fluorescence microscopy and flow cytometry, propidium iodide (PI) staining, annexin $\mathrm{V}$ assay, TUNEL assay and DNA ladder) for detection and quantification of cell death (apoptosis and necrosis) was evaluated and compared. Each of these methods detects different morphological or biochemical features of these two processes. The comparative analysis of the 8 techniques revealed that $\mathrm{AO} / \mathrm{EB}$ (read in fluorescence microscopy) provides a reliable method to measure cells in different compartments (or pathways) of cell death though it is very time consuming. PI staining and TUNEL assay were also sensitive in detecting very early signs of apoptosis, but do not allow precise quantification of apoptotic cells. These three methods were concordant in relation to induction of apoptosis and necrosis in HL60 cells with the various UV irradiation time periods tested. Both AO/EB (read by flow cytometry) and annexin V-FITC/PI failed to detect the same number of early apoptotic cells as the other three methods. Trypan blue is valueless for this purpose. Giemsa and DNA ladder might be useful as confirmatory tests in some situations.

Keywords: Apoptosis, necrosis, detection methods, microscopy, flow cytometry

\footnotetext{
*Correspondence to: J.E. Guimarães, IPATIMUP, Rua Dr. Roberto Frias, s/n, 4200 Porto, Portugal. Tel.: +351 225570 700; Fax: +351 225570 799; E-mail: jeguimaraes@ipatimup.pt.
}

\section{Introduction}

In eukaryotes there are two types of cell death, apoptosis and necrosis, that are primarily distinguished by morphology, but also differ in biochemical and molecular properties [2,16,23,40,52]. Necrosis is a pathological form of cell death, resulting in the loss of the cell ability to maintain homeostasis. It is morphologically associated with cell swelling, rapid rupture of cytoplasmic, organelle and nuclear membranes, followed by disintegration of organized structures. In contrast, apoptosis is a well-controlled, tightly regulated physiological process, in which the cell participates in its selfdestruction. Apoptosis involves chromatin condensation and margination, cell shrinkage, membrane blebbing and formation of apoptotic bodies. The biochemical event classically described as hallmark of apoptosis is internucleosomal digestion of DNA, that occurs by cleavage action of endonucleases, originating simple and multiple nucleosomes (180-200 bp), revealed as the typical "ladder" on agarose gels. DNA degradation can also occur in necrosis but randomly resulting in a smear pattern in DNA electrophoresis $[2,6,23,24$, 54,55]. Another biochemical event that was recently shown to be present is loss of plasma membrane asymmetry that occurs early in apoptosis $[14,49]$.

A large body of evidence has accumulated in the last few years suggesting that apoptosis is a central mechanism in embryogenesis and morphogenesis [23,24,38, $42]$, immune system regulation $[5,13,35,51]$, nervous system development [13,39], haematopoiesis [15,41, 53], control of turnover of normal tissues (maintenance of body homeostasis) and killing of virus-infected targets $[48,50,51,55]$. Apoptosis has been implicated in a variety of diseases. Failure of cells to undergo normal apoptotic cell death may be involved in the pathogenesis of cancer, autoimmune disorders and viral infections $[3,48,55]$. On the other hand increased cell loss by apoptosis is associated to a wide range of diseases, such as neurodegenerative disorders $[26,37,43$, 
48], acquired immunodeficiency syndrome [1,17,31] and myelodysplastic syndromes [56].

Since apoptosis is involved in a growing number of diseases, is induced by chemotherapeutic agents and has been associated with the appearance and development of pharmacological resistance [3,10,18,21], it is vital to have reliable methods of detection of cell death (apoptosis or necrosis). There is a considerable variety of methods of detection of cell death which are based on the different morphological or biochemical features of the two processes, such as changes in DNA content, DNA fragmentation, alteration of membrane integrity, loss of asymmetry of plasma membrane, and other morphological features of cells $[11,12,20,23,25$, $29,49,54]$.

In this study we evaluated and compared the reliability of eight distinct methods (Giemsa staining, trypan blue assay, acridine orange/ethidium bromide double staining for fluorescence microscopy and for flow cytometry, propidium iodide staining, Annexin $\mathrm{V}$, TUNEL assay and DNA ladder) for detection and quantification of apoptosis and necrosis in the HL60 human leukaemic cell line exposed to UV radiation for different lengths of time, as a model of induction of cell death.

\section{Material and methods}

\subsection{Cell culture}

HL60 human myeloid leukaemic cell line [9] was maintained in RPMI 1640 medium supplemented with $10 \%(\mathrm{v} / \mathrm{v})$ heat inactivated $\left(30 \mathrm{~min}, 56^{\circ} \mathrm{C}\right)$ foetal bovine serum (FBS) (Gibco BRL Life Technologies, Germany), $100 \mu \mathrm{l}$ streptomycin-100 U/ml penicillin, $2 \mathrm{mM}$ L-glutamine and $1 \mathrm{mM}$ sodium pyruvate (all from Gibco BRL Life Technologies, Paisley, Scotland). Cells were cultured in a $5 \% \quad \mathrm{CO}_{2}-95 \%$ air fully humidified atmosphere at $37^{\circ} \mathrm{C}$. The cultures were demi-populated 2-3 times a week, by dilution with fresh medium to a concentration of $0.25 \times 10^{6}$ cells/ml. Before each experiment, the cell concentration was adjusted to $0.5 \times 10^{6}$ cells $/ \mathrm{ml}$.

\subsection{Induction of cell death by irradiation}

Cell suspensions were transferred to Petri dishes of $58 \times 15$ mm (Nunc, Roskilde, Denmark), placed over an UV transilluminator (Vilber Lourmat, Marne La Vallée, France) and after 2-3 minutes of resting in or- der to form a single layer at the bottom of the dish were exposed to a $312 \mathrm{~nm}$ radiation (UV-B), at room temperature, for variable periods of time $(3 \mathrm{sec}, 15 \mathrm{sec}, 1 \mathrm{~min}$, $3 \mathrm{~min}, 5 \mathrm{~min}, 15 \mathrm{~min}, 25 \mathrm{~min}$ and $1 \mathrm{~h}$ ). Cultures were subsequently incubated under standard conditions $(5 \%$ $\mathrm{CO}_{2} ; 37^{\circ} \mathrm{C}$ ) for $4 \mathrm{~h}$ before analysing cell death by different methods.

Heat treatment of HL60 cells $\left(0.5 \times 10^{6}\right.$ cells $\left./ \mathrm{ml}\right)$ was performed in tissue culture tubes in water baths equilibrated to $37^{\circ} \mathrm{C}$ (control), $39^{\circ} \mathrm{C}, 45^{\circ} \mathrm{C}$ and $51^{\circ} \mathrm{C}$ for $15 \mathrm{~min}, 25 \mathrm{~min}$ and $1 \mathrm{~h}$, respectively.

\subsection{Measurement of cell death}

Cell death was measured by eight distinct methods:

\section{(1) Light microscopy analysis of cell death}

Control and irradiated cell suspensions were analysed under light microscopy by two methods: Giemsa staining and trypan blue exclusion assay. For Giemsa stain, cells were cytocentrifuged (Shandon, Pittsburg, PA, USA) $2 \mathrm{~min}$ at $500 \mathrm{rpm}$, fixed in $100 \%$ methanol (Merck, Darmstadt, Germany) and stained with Giemsa (Merck). The cytospin preparations were examined for nuclear, cytoplasmic and cell membrane changes in order to identify the type of cell death (apoptosis or necrosis) [23]. In the second method, cells were loaded in a haemocytometer in the presence of a $0.2 \%$ (final concentration) trypan blue solution (Sigma Chemical Company, St Louis, MO, USA) and scored (a minimum of 100 cells) for dye uptake (blue cells are dead cells). The percentage of dead cells was obtained by at least three independent measurements.

(2) Fluorescence microscopy analysis of cell deathacridine orangelethidium bromide (AO/EB) double staining

This method combines the differential uptake of fluorescent DNA binding dyes acridine orange and ethidium bromide and the morphological aspect of chromatin condensation in the stained nucleus, allowing one to distinguish between viable, apoptotic (early or late stages) and necrotic cells. The acridine orange is taken up by both viable and nonviable cells, and emits either green fluorescence, as a result of intercalation into double stranded nucleic acids (mainly DNA) or red fluorescence as a result of binding to nucleic acids of single strand (RNA). The ethidium bromide is only taken up by nonviable cells, and emits red fluorescence by intercalation into DNA. Thus a viable cell would have a uniform bright green nucleus and orange cytoplasm; an early apoptotic cell, whose membranes are 
still intact but has started to cleave its DNA would still have a green nucleus, but chromatin condensation becomes visible in the form of bright green patches; a late apoptotic cell would have bright orange areas of condensed chromatin in the nucleus (ethidium bromide predominates over acridine); and a necrotic cell will have an uniform bright orange nucleus [32].

One microlitre of dye mixture $[100 \mu \mathrm{g} / \mathrm{ml}$ acridine orange and $100 \mu \mathrm{g} / \mathrm{ml}$ ethidium bromide (from Polysciences, Warrington, PA, USA and Sigma, respectively), diluted in phosphate-buffered saline (PBS), $\mathrm{pH} 7.4$ ], was mixed gently with $24 \mu \mathrm{l}$ of cell suspension $\left(0.5 \times 10^{6}\right.$ cells $\left./ \mathrm{ml}\right)$ and put onto a clean microscope slide [32]. The suspension was immediately (dye uptake is very fast) examined in a fluorescence microscope (Olympus-BH2-RFCA, Olympus Optical Co., Lda, Tokyo, Japan), under 400-600× magnification. A minimum of 200 cells was counted in every sample and the percentage of cells recorded in four different groups: viable (V), early apoptotic (EA), late apoptotic (LA) and necrotic cells (N).

\section{(3) Flow cytometry analysis of cell death}

\section{(a) AO/EB double staining}

This method differs from the AO/EB double staining for fluorescence microscopy as it enables assessement of fluorescence intensity emitted by the fluorochromes. On the other side, morphological changes of chromatin would be missed and this parameter cannot be evaluated.

Cells $\left(0.5 \times 10^{6}\right)$ were pelleted at $300 \mathrm{~g}$, during $8 \mathrm{~min}$, resuspended in $495 \mu \mathrm{l}$ of ethidium bromide staining solution $(0.2 \mu \mathrm{g} / \mathrm{ml}$ in PBS $)$ and $5 \mu \mathrm{l}$ of acridine orange solution ( $2 \mu \mathrm{g} / \mathrm{ml}$ in PBS) were added, followed by a 30 min incubation, at room temperature. Then 10,000 cells were analyzed on a FacScan cytometer (Becton and Dickinson Immunocytometry Systems, San Jose, CA, USA) using a standard $488 \mathrm{~nm}$ argon laser. Green and red fluorescence were collected using a $525 \mathrm{~nm}$ band-pass (FL1) and a $650 \mathrm{~nm}$ longpass (FL3) filters, respectively, and displayed using logarithmic amplification. Data were analysed using LYSYS $^{\mathrm{TM}}$ II software.

\section{(b) PI staining (sub-G1 peak)}

The staining of normal cells with a specific DNA fluorochrome, as propidium iodide, defines a (conventional) cell cycle profile. During the apoptotic process internucleosomal DNA degradation occurs due to activation of an endogenous endonuclease [54] and subsequent production of low molecular weight DNA fragments. These fragments are lost after cell permeabilization, prior to measurement, resulting in the presence of cells with lower than G0/G1 (diploid) DNA content (sub-G1 peak), typical of apoptotic cells. Necrotic cells would show a normal cell cycle profile, until nuclear membrane bursts [11].

A volume of $750 \mu \mathrm{l}$ of ethanol (Merck pro-analysis) at $4{ }^{\circ} \mathrm{C}$ was added to $500 \mu \mathrm{l}$ of cell suspension $(0.5 \times$ $10^{6}$ cells $/ \mathrm{ml}$ in culture medium). Cells fixed in ethanol were kept at $4{ }^{\circ} \mathrm{C}$ during 24 hours. The next day the suspension was washed twice with $10 \mathrm{ml}$ of saline and centrifuged at $300 \mathrm{~g}$ for $8 \mathrm{~min}$. The pellet was resuspended in $500 \mu \mathrm{l}$ of PBS (pH 7.4) for a $10 \mathrm{~min}$ incubation. Cells were then spun and $250 \mu \mathrm{l}$ of propidium iodide solution [50 $\mu \mathrm{g} / \mathrm{ml}$ PI and $500 \mu \mathrm{g} / \mathrm{ml}$ RNase in $\mathrm{MgCl}_{2}$ buffer $(10 \mathrm{mM}$ Tris Base, $5 \mathrm{mM}$ $\mathrm{MgCl}_{2} \cdot 6 \mathrm{H}_{2} \mathrm{O}$ ), all from Sigma] were added to the pellet and left to incubate for $30 \mathrm{~min}$ at room temperature in the dark. Cells were centrifuged again and resuspended in $500 \mu \mathrm{l}$ of Isoton ${ }^{\circledR}$ (Coultronics France, Margency, France). Twenty thousand cells were analysed on the FacScan cytometer under low flow conditions. Red fluorescence was collected using a $575 \mathrm{~nm}$ bandpass filter (FL2) and displayed in linear amplification. Data were analysed using LYSYS ${ }^{\mathrm{TM}}$ II software.

\section{(c) TUNEL assay}

The TUNEL (TdT-mediated dUTP nick end labelling) method relies on the capacity of exogenous terminal deoxynucleotidyl transferase (TdT) to promote binding of fluorescein-labelled dideoxynucleotides (ddUTPs) to exposed $3^{\prime}-\mathrm{OH}$ ends of DNA strand breaks (both double and single strands). The fluorescence intensity, which is directly proportional to the number of DNA strand breaks (one molecule of ddUTP will bind to each break) is then evaluated by flow cytometry.

TUNEL was employed with slight modifications of the technique described by Piqueras et al. [36]. Briefly: $2 \times 10^{6}$ cells were fixed in $100 \mu 1$ of $4 \%$ paraformaldehyde (Merck) prepared freshly in PBS (pH 7.4), for $1 \mathrm{~h}$ in ice. Cells were then pelleted $\left(300 \mathrm{~g}, 1 \mathrm{~min}, 4^{\circ} \mathrm{C}\right)$ and washed once with $500 \mu \mathrm{l}$ cold PBS-1\% bovine serum albumin (BSA) (Sigma) before resuspending in $100 \mu \mathrm{l}$ ice-cold $70 \%$ ethanol. Cells were kept for at least $1 \mathrm{~h}$ at $-20^{\circ} \mathrm{C}$ and then washed 3 times at $4{ }^{\circ} \mathrm{C}$ with PBS- $1 \%$ BSA. Finally the pellet was resuspended in $50 \mu \mathrm{l}$ labelling buffer $(100 \mathrm{mM}$ potassium cacodylate, $1 \mathrm{mM} \mathrm{CoCl} 2,0.1 \mathrm{mM}$ dithiothreitol and $0.1 \mathrm{mg} / \mathrm{ml} \mathrm{BSA}$, all from Sigma) completed with 0.1 nmol F-12-ddUTP (Fluorescein-12-2'-dideoxyuridine- 
5'-triphosphate; Boehringer GmbH, Germany) and incubated $10 \mathrm{~min}$ on ice. Ten units of TdT (Gibco BRL) were then added for an incubation of $1 \mathrm{~h}$ at $37^{\circ} \mathrm{C}$. After addition of $2 \mu \mathrm{l}$ of $0.5 \mathrm{M}$ EDTA (to block TdT reaction), cells were washed three times in PBS-1\% BSA immediately before analysis of 10,000 cells on the FacScan cytometer with a standard argon laser and a bandpass filter for FL1. Data analysis was performed using LYSIS ${ }^{\mathrm{TM}}$ II software. Three controls following the same experimental procedure were set up: for control 1 (autofluorescence control) neither F-12-ddUTP nor TdT were added to the cultures; for control 2 (background reaction control) F-12-ddUTP (but not TdT) was added, and for control 3 (irradiation control) both F-12-ddUTP and TdT were added but cells were not exposed to the UV.

\section{(d) Annexin V assay}

This assay is based on the ability of the protein annexin $\mathrm{V}$ to bind to phosphatidylserine (PS) in the presence of calcium. In viable cells PS is located in the inner membrane leaflet, therefore annexin $\mathrm{V}$ can not detect it since it is not able to penetrate the phospholipid bilayer. Upon induction of apoptosis PS is translocated to the outer membrane leaflet and becomes available for annexin $\mathrm{V}$ binding [50]. The addition of propidium iodide (PI) to annexin $\mathrm{V}$ stained cells allows discrimination between viable cells (annexin- $\mathrm{V}^{\text {neg }} / \mathrm{PI}^{\text {neg }}$ ), early apoptotic (annexin- $\mathrm{V}^{\mathrm{pos}} / \mathrm{PI}^{\text {neg }}$ ), and late apoptotic and necrotic cells (annexin- $\mathrm{V}^{\mathrm{pos}} / \mathrm{PI}^{\mathrm{pos}}$ ) [25,49].

Annexin V assay was performed using a commercial kit (Apoptosis detection kit, Oncogene Research Products, Calbiochem, MA, USA). Briefly: Ten microlitre of media binding reagent and $1.25 \mu \mathrm{l}$ of annexin $\mathrm{V}(200 \mu \mathrm{g} / \mathrm{ml})$ conjugated to FITC were added to $0.5 \times 10^{6}$ cells in $500 \mu \mathrm{l}$ of culture medium and left to incubate for $15 \mathrm{~min}$ at room temperature (RT) in the dark. The suspension was centrifuged at $1000 \mathrm{~g}$ for $5 \mathrm{~min}$ at RT and the pellet resuspended in $500 \mu \mathrm{l}$ of $1 \times$ binding buffer with $10 \mu \mathrm{l}$ of propidium iodide. The suspensions were placed on ice away from light and immediately analysed by flow cytometry. Twenty thousand cells were analysed on the FacScan cytometer under low flow conditions. Green and red fluorescence were collected using FL1and FL2 filters, respectively, and displayed in logarithmic amplification. Electronic compensation (subtraction of $25 \%$ of FL-2 from FL-1) was required for the annexin V/PI assay. Data were analysed using LYSYS ${ }^{\mathrm{TM}}$ II software.

\section{(4) Detection of internucleosomal DNA fragmentation by electrophoresis (DNA ladder)}

This procedure is based on the observation of a distinctive ladder pattern of approximately 200-bp integer multiples DNA fragments in agarose gel electrophoresis. This comes as a result of DNA cleavage between nucleosomes by an endogenous endonuclease involved in apoptosis.

DNA fragmentation was analysed by the gel electrophoresis method according to Smith et al. [44]. Briefly, $10^{6}$ cell pellets were incubated, at $50^{\circ} \mathrm{C}$ for $1 \mathrm{~h}$, with $20 \mu \mathrm{l}$ of $10 \mathrm{mM}$ EDTA-50 mM Tris$\mathrm{HCl}(\mathrm{pH} 8.0)$ containing $0.5 \%(\mathrm{w} / \mathrm{v})$ sodium lauryl sarkosinate (Sigma) and $0.5 \mathrm{mg} / \mathrm{ml}$ proteinase K (Calbiochem, La Jolla, CA, USA). Then, $10 \mu \mathrm{l}$ of 0.5 $\mathrm{mg} / \mathrm{ml}$ DNase-free RNase (Sigma) were added to each sample and incubation continued at $50^{\circ} \mathrm{C}$ for $1 \mathrm{~h}$. Samples were heated in a $70^{\circ} \mathrm{C}$ water bath, and $10 \mu \mathrm{l}$ of $10 \mathrm{mM}$ EDTA containing $1 \%$ (w/v) low-gellingtemperature agarose, $40 \%(\mathrm{w} / \mathrm{v})$ sacarose and $0.25 \%$ (w/v) bromophenol blue were mixed with each sample before loading into the dry wells of a $2 \%(\mathrm{w} / \mathrm{v})$ agarose gel containing $0.1 \mu \mathrm{g} / \mathrm{ml}$ ethidium bromide (all from Sigma). A 100 bp (Gibco BRL) standard was used to provide molecular weight markers. Electrophoresis was carried out in $2 \mathrm{mM}$ EDTA- $800 \mathrm{mM}$ Tris-borate (pH 8.0) until the marker dye migrated 3-4 cm.

\section{Results}

\subsection{Light microscopy analysis of cell death}

\subsubsection{Giemsa staining}

HL60 cells exposed to UV radiation during short periods ( $3 \mathrm{sec}, 15 \mathrm{sec}, 30 \mathrm{sec}, 1 \mathrm{~min}$ and $3 \mathrm{~min}$ ) showed morphological features of apoptosis in cytospins stained with Giemsa: cell shrinking, chromatin condensation and nuclear fragmentation. Prolonged exposure (15 min, $25 \mathrm{~min}$ and $1 \mathrm{~h}$ ) of these cells to the same level of UV radiation induced nuclear and cytoplasmic swelling with chromatin appearing uniformly dense and rupture of plasma membrane, resulting in decreased definition of cellular outlines that are typical of necrosis. The various morphological types are shown in Fig. 1.

\subsubsection{Trypan blue exclusion assay}

The viability of HL60 cells, exposed to UV radiation, was evaluated by the trypan blue exclusion assay and results are represented in Fig. 2. Loss of viability was evident for periods of irradiation longer than 


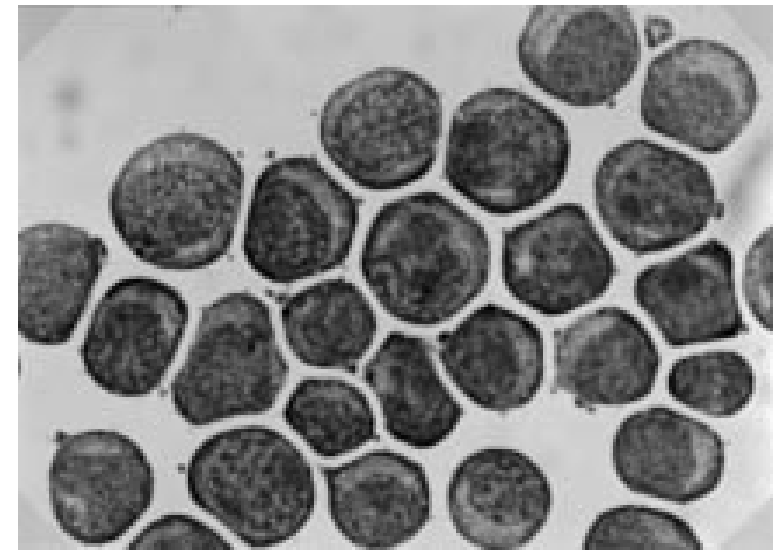

A

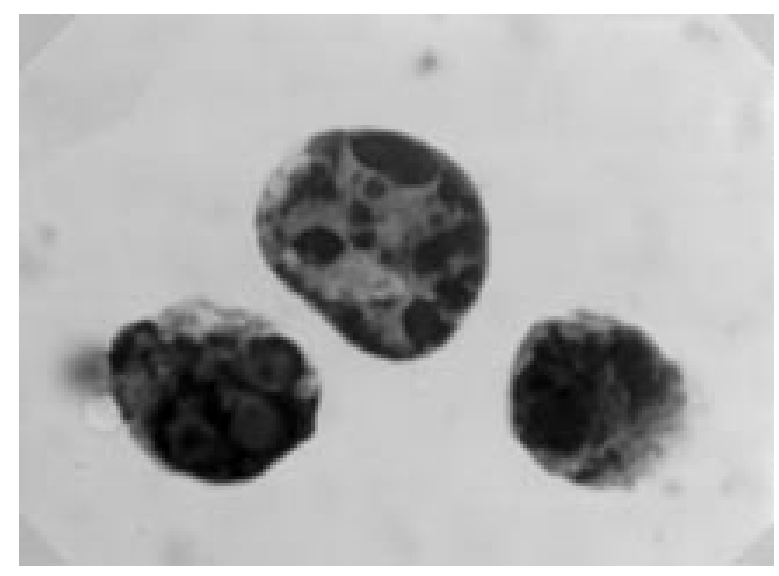

B

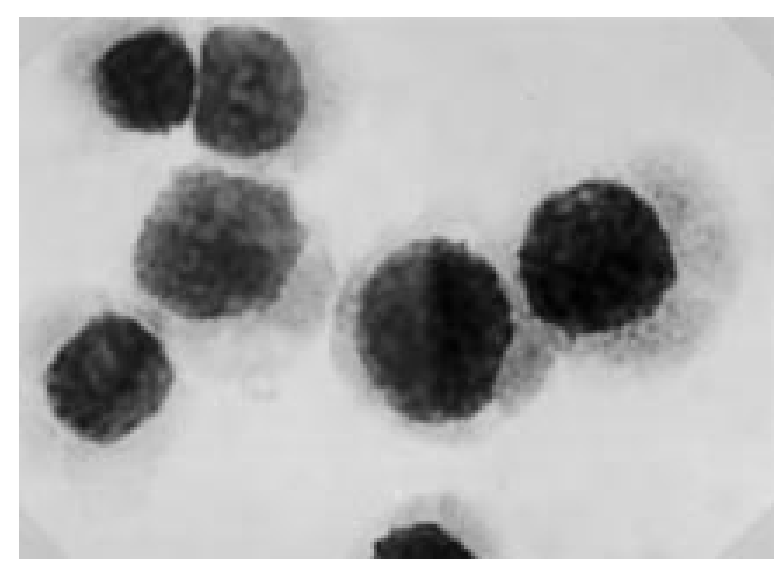

C

Fig. 1. Cytospins of HL60 cells stained with Giemsa showing morphological characteristics of: (A) unirradiated cells (control); (B) apoptotic cells after $15 \mathrm{sec}$ of UV radiation and (C) necrotic cells after $1 \mathrm{~h}$ exposure to $\mathrm{UV}$ radiation. A, $\times 400$ magnification; $\mathrm{B}$ and $\mathrm{C}$, $\times 1000$ magnification.
Viability of HL60 cells by trypan blue and acridine orange/ethidium bromide

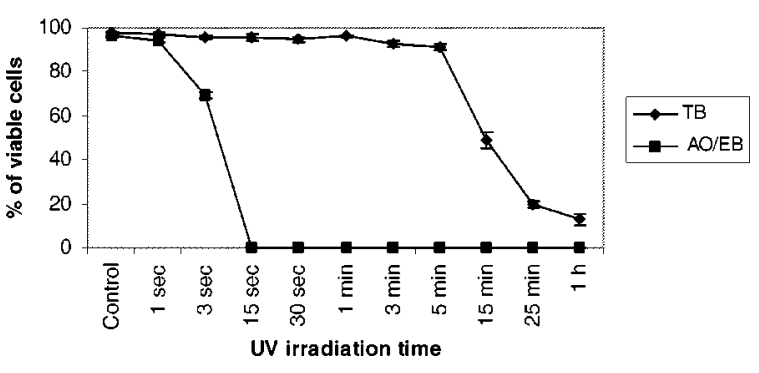

Fig. 2. Comparison of percentage of viable HL60 cells as measured by two different methods: trypan blue exclusion assay (- - TB) and $\mathrm{AO} / \mathrm{EB}$ double staining (- - ; $\mathrm{AO} / \mathrm{EB})$. The results represent the mean of five independent experiments \pm standard error.

5 min. HL60 cells irradiated during 1 hour still presented $13 \%$ of viable cells by trypan blue, but cells that excluded the dye and were therefore considered as viable had a vitreous appearance, considerably different in morphology from control cells.

\subsection{Fluorescence microscopy analysis of cell death- AO/EB double staining}

Irradiated and non-irradiated HL60 cells were stained with $\mathrm{AO} / \mathrm{EB}$ and analysed under a fluorescence microscope for the percentage of viable, early apoptotic, late apoptotic and necrotic cells. The results obtained with this double staining are represented in Fig. 4, and Fig. 3 shows the different morphology of cells stained with AO/EB double staining classified according to the described in Material and methods. Cultures irradiated for $3 \mathrm{sec}$ showed a decrease in number of viable cells when compared with control, with a concomitant increase in number of early apoptotic cells $(26.6 \%)$. Cells irradiated for $15 \mathrm{sec}$ to $5 \mathrm{~min}$ showed $100 \%$ of death with early apoptotic cells as the predominant cell type (around 95\%). Cultures irradiated for $15 \mathrm{~min}, 25 \mathrm{~min}$ and $1 \mathrm{~h}$ showed an increasing number of necrotic cells, and a concomitant decrease in the number of early apoptotic cells. The percentage of late apoptotic cells remain approximately constant independently of time of irradiation (Fig. 4).

The viability of HL60 cells evaluated by AO/EB double staining was compared with that evaluated by trypan blue staining and the results are represented in Fig. 2. HL60 cells irradiated for periods of time as short as $3 \mathrm{sec}$ present a relevant loss of viability, which was not detected by trypan blue staining and cells irradiated for $15 \mathrm{sec}$ or more had $0 \%$ viability, value never reached by trypan blue staining. 


\subsection{Flow cytometry analysis of cell death}

\subsubsection{AO/EB double staining}

HL60 cells were stained by AO/EB and analysed by flow cytometry (Fig. 5). In AO/EB fluorescence biparametric contour plots (green fluorescence of $\mathrm{AO}$, FL1, versus red fluorescence of EB, FL3) it was possible to observe three distinct populations of HL60 cells similarly to the reported by Liegler et al. [29]: population $1\left(\mathrm{AO}^{\text {high }}-\mathrm{EB}^{\text {low }}\right)$ of viable cells, population $2\left(\mathrm{AO}^{\text {low }}-\mathrm{EB}^{\text {low }}\right)$ of early apoptotic cells and popula-

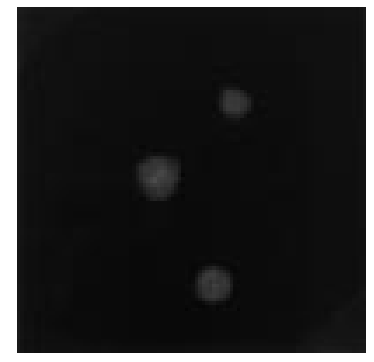

A

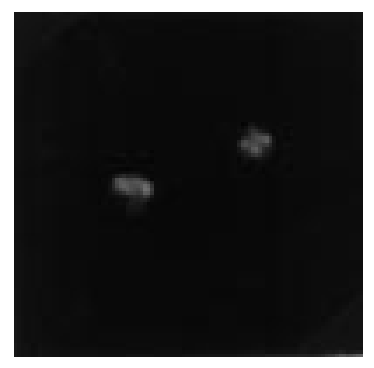

C

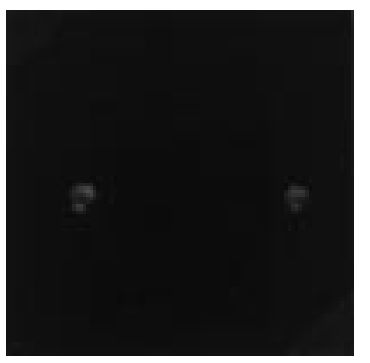

B

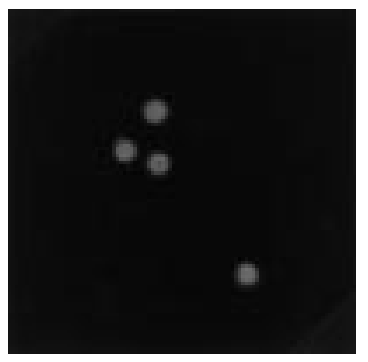

$\mathrm{D}$
Fig. 3. Morphology of HL60 cells stained by acridine orange/ ethidium bromide: A, viable cells; B, early apoptotic cells; C, late apoptotic cells; and D, necrotic cells. $\times 200$ magnification. tion $3\left(\mathrm{AO}^{\text {low }}-\mathrm{EB}^{\text {high }}\right)$ of late apoptotic and necrotic cells.

Non-irradiated HL60 cells appear mostly in region 1 with a small percentage in region 2 and even in region 3 , corresponding to spontaneous apoptosis occurring in the cultures (Fig. 5A). Periods of irradiation between $3 \mathrm{sec}$ and $3 \mathrm{~min}$ induced apoptosis, detectable essentially in early phase (region 2 ). It could be noticed however an increased dispersion in the contour of region 1 (Fig. 5(B and C)). After 25 min of irradiation, HL60 cells are located in region 3 (Fig. 5(D and E)). The intermediate periods of irradiation showed a continuum of cells between region 2 and 3 (data not shown).

Since acridine orange is a metachromatic dye it was necessary to perform single staining with acridine orange and ethidium bromide to test whether red fluorescence of $\mathrm{AO}^{\text {low }}-\mathrm{EB}^{\text {high }}$ population (region 3 ) in double staining was due to binding of EB to DNA or to AO binding to single stranded nucleic acids (namely RNA) in the cells. Thus, by comparative analysis of cells stained with AO only and with AO/EB simultaneously it was possible to conclude that the red fluorescence of cells in region 3 was the result of entry and binding of EB to DNA of cells with altered membrane and not due to emission of red fluorescence by $\mathrm{AO}$, since it was not detected a population of cells in region 3 (high red fluorescence) in cells stained with AO alone (data not shown).

\subsubsection{PI staining (sub-G1 peak)}

HL60 cells previously fixed with ethanol were stained with propidium iodide and analysed by flow cytometry.

An irradiation time as short as 3 seconds resulted in the accumulation of a distinct subpopulation of apoptotic cells to the left of the G0/G1 peak (sub-G1 peak)

\section{HL60 cells by acridine orange/ethidium bromide}

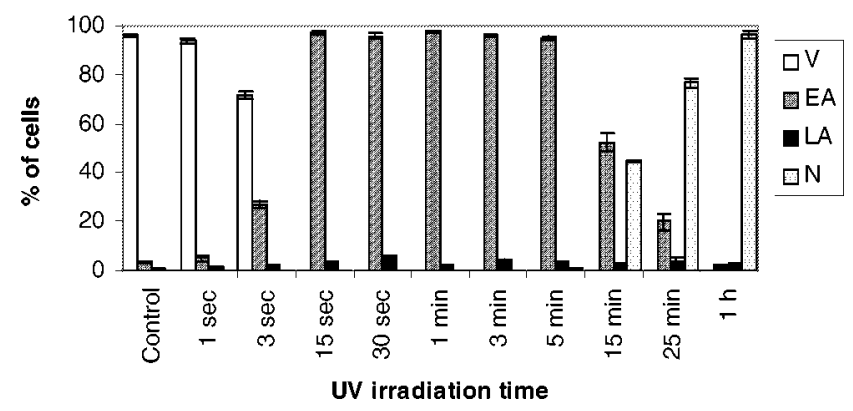

Fig. 4. Percentage of HL60 cells evaluated by acridine orange/ethidium bromide. V, viable cells; EA, early apoptotic cells; LA, late apoptotic cells; and N, necrotic cells. The results represent the mean of at least three independent experiments \pm standard error. 

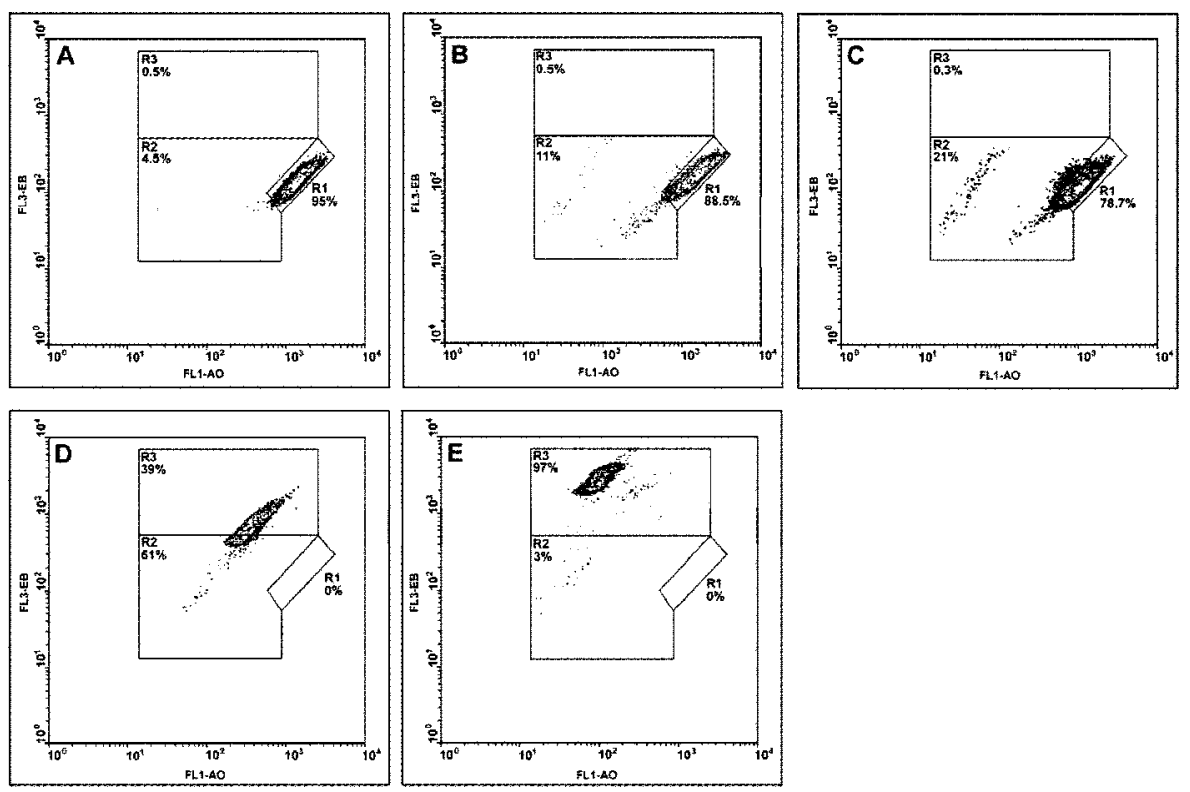

Fig. 5. Biparametric contour plots of green fluorescence (FL1, $x x^{\prime}$ axis) versus red fluorescence (FL3, yy' axis) of HL60 cells stained simultaneously with $\mathrm{AO}$ and $\mathrm{EB}$. Region $1(\mathrm{R} 1)$ of $\mathrm{AO}^{\text {high }}-\mathrm{EB}^{\text {low }}$ staining corresponds to viable cells; early apoptotic cells are distributed to region 2 (R2) $\left(\mathrm{AO}^{\text {low }}-\mathrm{EB}^{\text {low }}\right)$, and late apoptotic and necrotic cells are distributed to region 3 (R3) ( $\left.\mathrm{AO}^{\text {low }}-\mathrm{EB}^{\text {high }}\right)$. $\mathrm{A}$, control culture; $\mathrm{B}, \mathrm{C}, \mathrm{D}$ and $\mathrm{E}$, cells irradiated for $3 \mathrm{sec}, 15 \mathrm{sec}, 25 \mathrm{~min}$ and $1 \mathrm{~h}$, respectively. Percentages of R1, R2 and R3 cells are shown in the figures. One representative experiment out of three is shown.

while the remaining viable cells were distributed to the different phases of cell cycle (Fig. 6B). Irradiation of cultures for $15 \mathrm{sec}$ induced $100 \%$ of cell death by apoptosis, which is demonstrated by the formation of a single peak in the sub-G1 region (Fig. 6C). The same happened with cultures irradiated for $30 \mathrm{sec}, 1 \mathrm{~min}, 3 \mathrm{~min}$ and 5 min (data not shown). DNA content of cultures exposed to longer periods of radiation $(15 \mathrm{~min}, 25 \mathrm{~min}$ and $1 \mathrm{~h}$ ), is similar to non-irradiated HL60 cells that distributed to the G1, S and G2/M phases of the cell cycle displaying a residual percentage of dead cells which did not form however a sub-G1 peak (Fig. 6(A and D)).

Analysis of the different HL60 cell cycle histograms is not able to support that any compartment of the cell cycle is preferentially affected by UV radiation.

To investigate whether the sub-G1 peak detected in some irradiated cultures was actually formed by apoptotic cells or by an accumulation of cellular debris in that region, control and irradiated cells stained with PI were analyzed by flow cytometry using logarithmic amplification. By this means we were able to observe that cellular debris had a lower fluorescence intensity forming a continuum from zero to the sub-G1 peak (Fig. 6(inserts E and F)).

\subsubsection{TUNEL assay}

HL60 cells exposed to UV showed various kinetics of F-12-ddUTPs incorporation according to time of exposure to radiation as it can be observed in Fig. 7(A and B). Cells irradiated for $3 \mathrm{sec}$ showed a slight increase of incorporation of fluorescent nucleotide compared to control cultures. Cells exposed for $15 \mathrm{sec}, 3 \mathrm{~min}$, $25 \mathrm{~min}$, and $1 \mathrm{~h}$ to $\mathrm{UV}$ had a pattern of incorporation of fluorescent dideoxynucleotides which is distinctly greater than the displayed by control cells (Fig. 7). Exposure to UV during $30 \mathrm{sec}, 5 \mathrm{~min}$, and $15 \mathrm{~min}$ had a similar pattern (data not shown).

To investigate whether the increase of F-12-ddUTPs incorporation was due to internucleosomal fragmentation of apoptosis or to DNA breaks formed as a result of UV radiation, we decided to perform the TUNEL assay in irradiated cultures immediately after UV radiation suppressing the 4-hour incubation period (Fig. 7B). It was observed that there was no incorporation of fluorescent nucleotides in HL60 cells irradiated for $3 \mathrm{sec}, 15 \mathrm{sec}$ and $30 \mathrm{sec}$ and not incubated for $4 \mathrm{~h}$ in standard conditions (Fig. 7B). In cultures irradiated during $3 \mathrm{~min}$ and $5 \mathrm{~min}$, not followed by incubation period, some incorporation of fluorescent nucleotides occurred relatively to the control but in every case lower than the incorporation observed in the cells submitted 

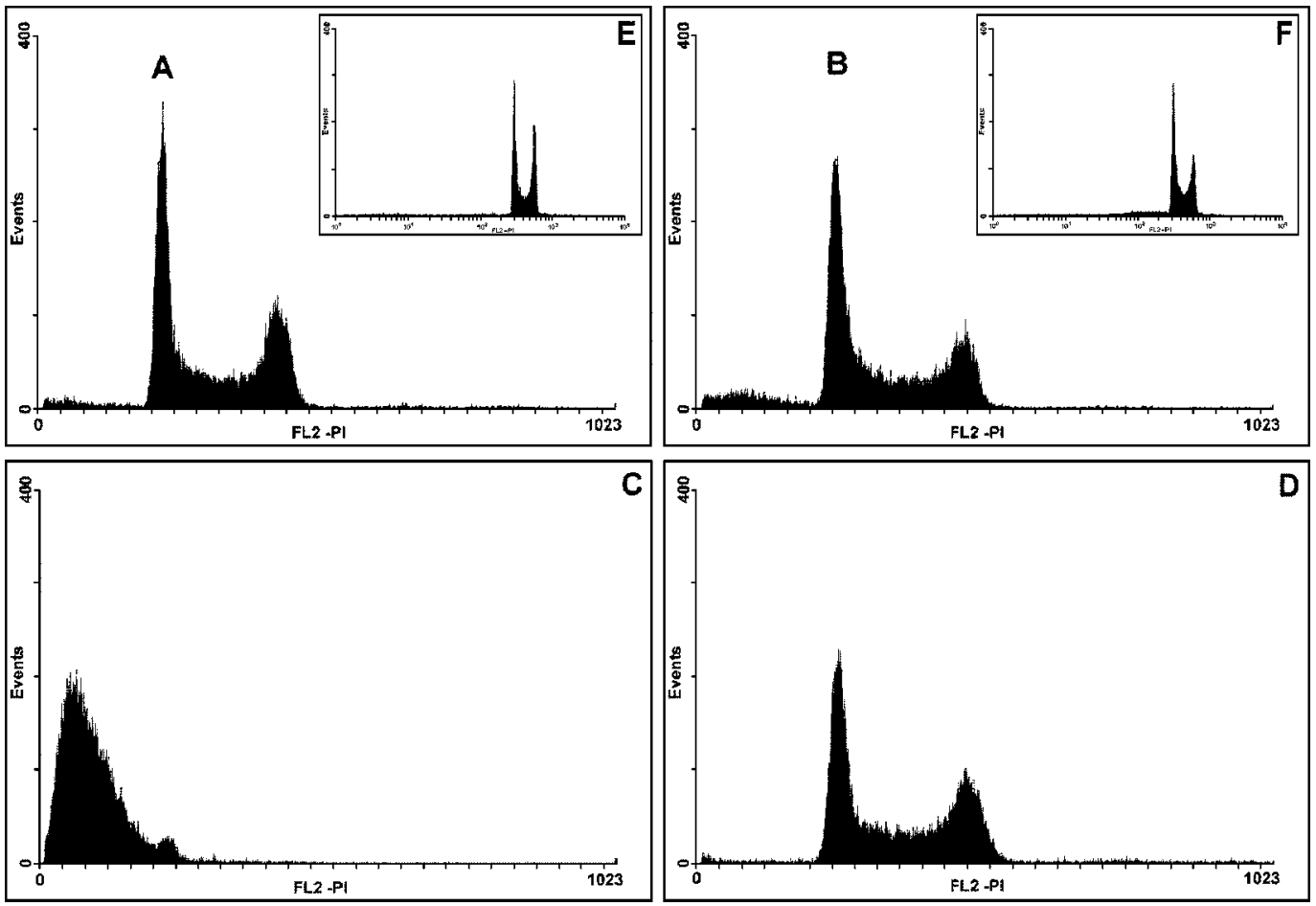

Fig. 6. Propidium iodide fluorescence (DNA content) histograms of HL60 cells after exposure to UV irradiation. A, control culture (non-irradiated). B, C and D, cells irradiated for $3 \mathrm{sec}, 15 \mathrm{sec}$ and $15 \mathrm{~min}$, respectively. These irradiation times are representative of the other times depicted in the text. E and F, same as A and B but using logarithmic amplification. One representative experiment out of three is shown.
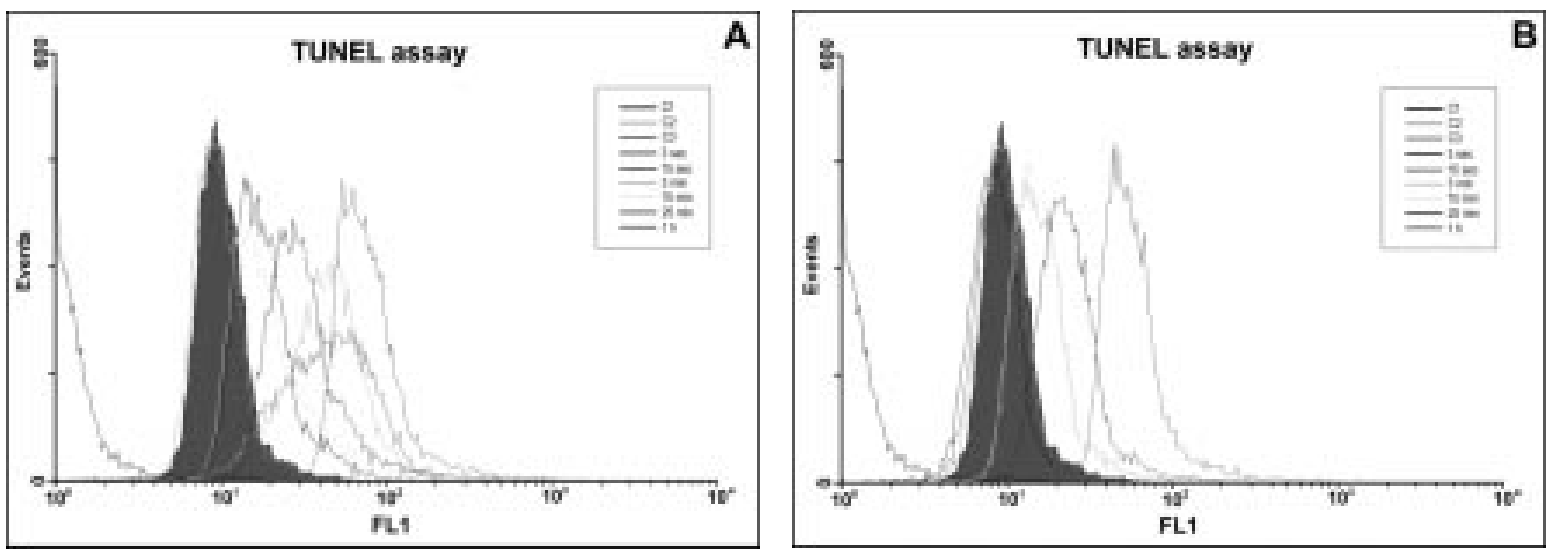

Fig. 7. Fluorescein-12-ddUTP incorporation mediated by exogenous terminal deoxynucleotidyl transferase (TdT) - TUNEL assay, in DNA of HL60 cells. A, cells submitted to a 4-hour period of incubation after irradiation during $3 \mathrm{sec}, 30 \mathrm{sec}, 3 \mathrm{~min}, 15 \mathrm{~min}, 25 \mathrm{~min}$ and $1 \mathrm{~h}$. B, cells without the 4-hour incubation period, after irradiation for the same time periods. C1, negative control of autofluorescence; $\mathrm{C} 2$, negative control of background/reaction; C3, non-irradiated control cells. Only representative exposure times are shown in the figure, other times referred to in the text have a similar profile.

to incubation (Fig. 7B). For $15 \mathrm{~min}, 25 \mathrm{~min}$, and $1 \mathrm{~h}$ irradiated cells with no incubation period, it was observed a F-12-ddUTP incorporation higher than in control cultures, and identical to cultures submitted to the 4-hour incubation.

\subsubsection{Annexin V assay}

The combined analysis of HL60 cells with annexin V-FITC and propidium iodide by flow cytometry allowed the discrimination between viable cells, early and late apoptotic cells and necrotic cells (Fig. 8). 

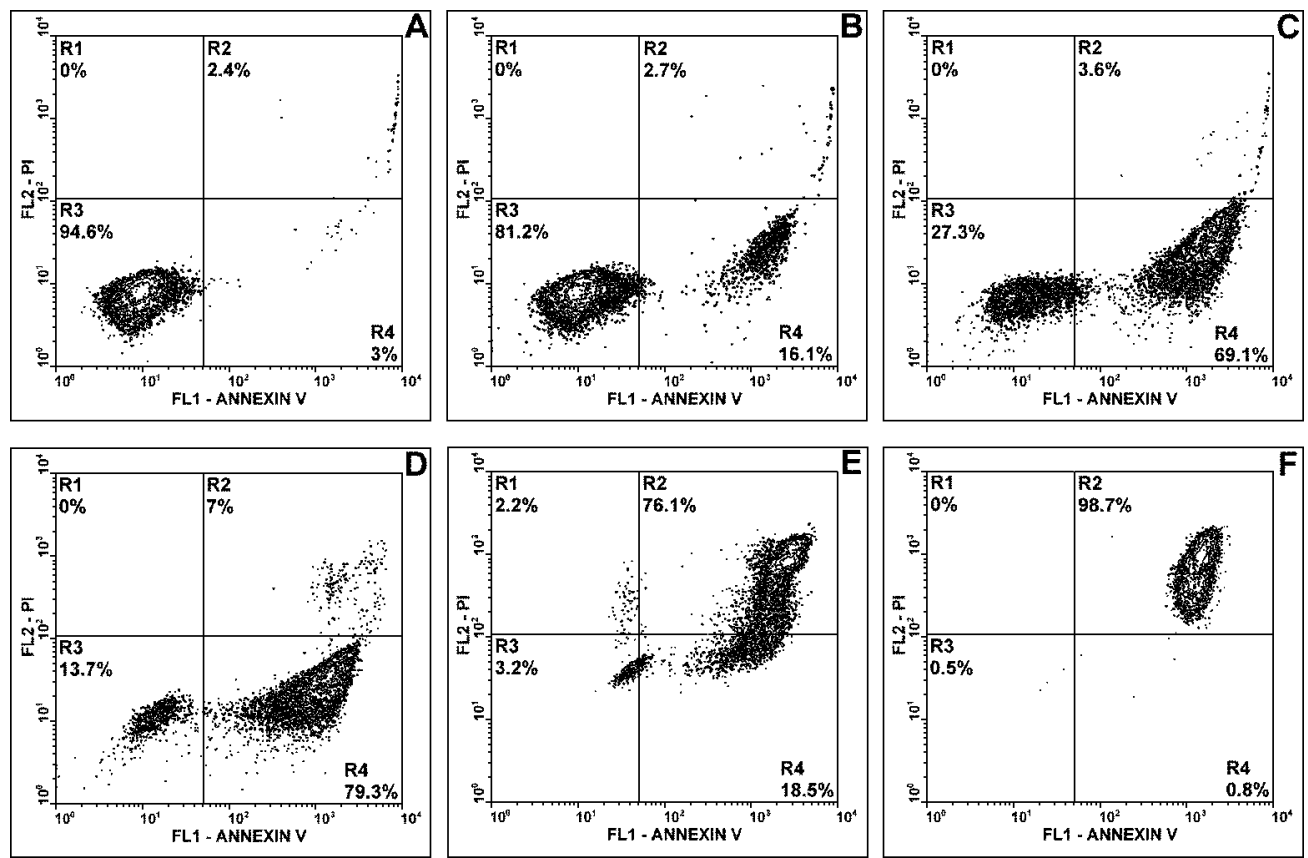

Fig. 8. Biparametric contour plots of annexin V-FITC (green fluorescence, FL1, $x x^{\prime}$ axis) versus propidium iodide (red fluorescence, FL2, yy' axis) of UV-irradiated HL60 cells. Region 1 (R1) corresponds to damaged cells (annexin-V $\mathrm{V}^{\text {neg }} / \mathrm{PI}^{\mathrm{pos}}$ ); region 2 (R2) contains necrotic and late apoptotic cells (annexin- $\mathrm{V}^{\text {pos }} / \mathrm{PI}^{\mathrm{pos}}$ ); region 3 (R3) contains viable cells (annexin- $\mathrm{V}^{\text {neg }} / \mathrm{PI}^{\text {neg }}$ ) and region 4 (R4) contains early apoptotic cells (annexin- $\mathrm{V}^{\text {pos }} / \mathrm{PI}^{\text {neg }}$ ). A, control culture; B, C, D, E and F, cells irradiated for $3 \mathrm{sec}, 15 \mathrm{sec}, 5 \mathrm{~min}, 25$ min and $1 \mathrm{~h}$, respectively. Percentages of $\mathrm{R} 1, \mathrm{R} 2, \mathrm{R} 3$ and R4 cells are shown in the figures. One representative experiment out of three is shown.

Non-irradiated cultures had predominantly viable cells $(94.6 \%)$ that are located in region 3 and a small percentage of spontaneous apoptotic cells in region 4 (3\%) and region 2 (2.4\%) (Fig. 8A). Periods of irradiation between $3 \mathrm{sec}$ and 5 min induced mainly apoptosis detectable in early phases (region 4) but a small percentage of late apoptotic and necrotic cells were found (region 2), as it can be observed in Fig. 8(B, C and D). HL60 cultures irradiated for $1 \mathrm{~h}$ presented almost $100 \%$ of cells in region 2, but with $15 \mathrm{~min}$ and $25 \mathrm{~min}$ UV irradiation there are still some cells detected in region 4 correspondent to early apoptotic cells (Fig 8E).

\subsection{Detection of internucleosomal DNA \\ fragmentation by electrophoresis (DNA ladder)}

In order to investigate whether morphological changes observed in irradiated HL60 cells were in agreement with chromatin degradation patterns commonly associated to apoptosis or necrosis, DNA extraction of cells exposed to different times of UV radiation was followed by electrophoresis in $2 \%$ agarose gel. Figure 9 illustrates the DNA fragmentation pattern typical of apoptosis (DNA ladder) in HL60 cells irradi-

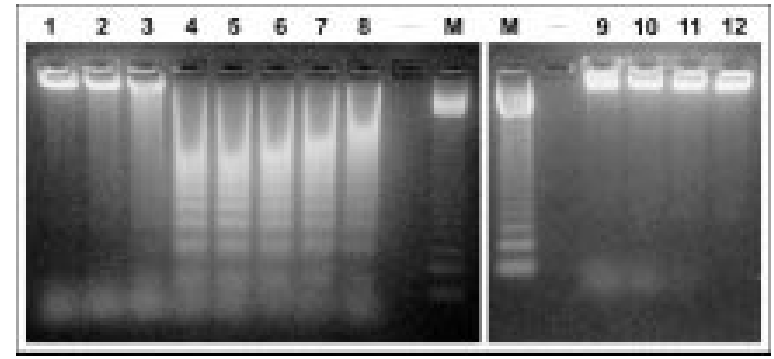

Fig. 9. Agarose gel electrophoresis of DNA extracted from HL60 cells after exposure to UV irradiation and further incubation during $4 \mathrm{~h}$ at $37^{\circ} \mathrm{C}$. DNA fragmentation typical of apoptosis (DNA ladder) was observed in cultures irradiated during $15 \mathrm{sec}$ (lane 4), $30 \mathrm{sec}$ (lane 5), 1 min (lane 6), 3 min (lane 7) and 5 min (lane 8). No specific DNA cleavage was shown in control cultures (lane 1) and in cultures exposed to $1 \mathrm{sec}$ (lane 2), $3 \mathrm{sec}$ (lane 3), $10 \mathrm{~min}$ (lane 9), $15 \mathrm{~min}$ (lane 10), $25 \mathrm{~min}$ (lane 11) and $1 \mathrm{~h}$ (lane 12) of UV irradiation. M lanes represent a molecular weight size standard (100 base pairs). One representative experiment out of three is shown.

ated during short periods of time. In cells irradiated for periods longer than $10 \mathrm{~min}$, this specific DNA cleavage pattern was not observed. HL60 cells irradiated during $1 \mathrm{sec}$ and $3 \mathrm{sec}$ did not show DNA ladder fragmentation similarly to control cells (Fig. 9). 


\section{Discussion}

In the current study we evaluated and compared several different methods for detecting cell death (either apoptosis or necrosis), using UV irradiation of HL60 cell line as a model.

Since apoptosis is involved in multiple physiological and pathological processes and is induced by most cytotoxic drugs used in treatment of neoplastic diseases it is important not only to quantify the percentage of death but also to identify the type of cell death. A variety of methods are now available to detect and quantify apoptosis, based on parameters as different as changes in DNA content, DNA fragmentation, chromatin condensation, alteration of membrane integrity, loss of asymmetry of plasma membrane, and other morphological characteristics of cells.

Apoptosis was originally distinguished from necrosis on the basis of cell ultrastructure [22,23] and electron microscopy (EM) is still considered the most reliable method for recognising these two processes. However their applicability to routine is restricted. The classical alternative to EM method is Giemsa staining which also allows recognition of the main morphological features of the cells. However apoptotic and necrotic cells in advanced phase of deterioration and apoptotic bodies without chromatin are frequently lost in cytospin preparations thereby biasing the results towards underestimation of cell death.

All methods tested except AO/EB by flow cytometry and annexin V-FITC/PI assay were concordant in relation to induction of apoptosis and necrosis in the various irradiation time periods tested. Thus, $15 \mathrm{sec}$ of exposure to UV induced $100 \%$ of apoptosis. The same happened with all time periods through $5 \mathrm{~min}$ of irradiation. Fifteen min, $25 \mathrm{~min}$ and $1 \mathrm{~h}$ of irradiation induced necrosis in an increasing percentage of cells. Three-sec of irradiation induced a relevant percentage of apoptosis as measured by microscopical evaluation of AO/EB staining (26.6\% of cells) and this result was confirmed by PI (sub-G1 peak), and TUNEL as well as by Giemsa staining. Thus, up to $5 \mathrm{~min}$ of exposure to UV, almost all cells were in apoptosis, while longer irradiation periods resulted in necrosis. These results were not in agreement with those obtained by other authors that used the same model of cell death induction (UV radiation). Martin and Cotter [30] found that HL60 cells irradiated for different time periods up to $30 \mathrm{~min}$ died by apoptosis and cells irradiated for 1 and $2 \mathrm{~h}$ died by necrosis. Similarly Lennon and colleagues [28] referred that 10 min of irradiation induced apoptosis while $2 \mathrm{~h}$ of irradiation induced necrosis. In both cases the cultures were analyzed for cell death after $4 \mathrm{~h}$ of incubation in standard conditions. These differences to our results can be explained by the different methodology we used: Martin and Cotter [30] placed the cell cultures at a distance of $2.5 \mathrm{~cm}$ of the UV transilluminator source, Lennon et al. [28] irradiated the cells at a distance of $1.5 \mathrm{~cm}$ of the source while we placed the cultures directly onto the transilluminator. To exclude the possibility that the cells were dying as a result of hyperthermia we measured the temperature reached at which the cells were exposed. In fact for exposure periods of 25 min or longer, temperature was above physiological limits $\left(42.2^{\circ} \mathrm{C}\right.$ for $25 \mathrm{~min}, 47.6^{\circ} \mathrm{C}$ for $1 \mathrm{~h}$, at the end of the irradiation period). These temperatures may be responsible for some percentage of cell death but this fact does not invalidate results achieved up to $15 \mathrm{~min}$ of irradiation.

It is well known that apoptotic cells stained with propidium iodide after fixation show a decrease in fluorescence intensity, resulting in the appearance of a welldefined subpopulation in the cell cycle profile, the subG1 cells $[11,46]$. This holds for staining with other DNA binding or intercalating agents [47] and is probably due to the fact that small pieces of DNA resulting from chromatin fragmentation may leak from the cell after permeabilization [11].

The utilisation of the sub-G1 peak method for evaluation of the percentage of apoptotic cells in a given population may have however some pitfalls: it is likely that apoptotic cells originally in $\mathrm{S}$ or $\mathrm{G} 2 / \mathrm{M}$ phases which enter apoptosis may fall into other cell cycle compartments after loss of fragments of DNA, thereby being located in regions other than the sub-G1 region and leading to underestimation of the percentage of apoptotic cells [45]. However, our results suggest that this might not be a real problem as it does not appear to be any significant change in the prevalent cell cycle profile observed. Also, the sub-G1 peak may include apoptotic bodies, rendering quantification of apoptotic cells difficult. Lastly, it is important to keep in mind that not all cell types have the same tendency to form apoptotic bodies. While HL60 cells rapidly form apoptotic bodies, MOLT-4 cells, for example, do not [4]. For detection of cell death by necrosis this method alone is not useful since necrotic cells show the same cell cycle profile as control cells, as we observed in this study when HL60 cells were irradiated for time periods longer than $15 \mathrm{~min}$. However this method is rapid and enables identification of apoptosis.

DNA ladder detected in agarose gel electrophoresis was considered to be the hallmark of apoptosis 
for a long time. However in some situations cells that ultrastructurally may be defined as apoptotic do not show the ladder pattern $[7,33]$ and cells that ultrastructurally appear as necrotic show it [8]. Some of these "false negative" can be explained by the fact that in some cases of apoptosis DNA cleavage results in formation of high molecular weight fragments $(300 \mathrm{kbp}$ and $50 \mathrm{kbp}$ ) which cannot be revealed by conventional electrophoresis that detect DNA ladder [33]. This methodology does not appear to be as sensitive as others tested as DNA ladder was not detected in samples with approximately $30 \%$ of apoptotic cells and less, which was the case for cells exposed for $3 \mathrm{sec}$ to UV. However this method is still useful, since it allows assessment of one important biochemical event characteristic of apoptosis.

The TUNEL assay enabled detection of DNA breaks for an UV irradiation time of $3 \mathrm{sec}$ but it was unable to discriminate between apoptosis (15 sec to $5 \mathrm{~min}$ of exposure) and necrosis (15 $\mathrm{min}$ to $1 \mathrm{~h}$ ) in our model. Grasl-Kraupp et al. [19] also observed, using several models of induction of apoptosis and necrosis other than UV, that TUNEL assay was not specific for apoptosis, since positive reaction for TUNEL appeared in necrotic hepatocytes. When we analyzed cells without the $4 \mathrm{~h}$-incubation period it was possible to observe that time periods of irradiation of $15 \mathrm{~min}$ or longer had the same pattern of incorporation of the corresponding time periods with the $4 \mathrm{~h}$-incubation. This suggests that direct effect of UV for longer periods of exposure was able to induce DNA breaks per se. Thus, TUNEL assay revealed few advantages over $\mathrm{AO} / \mathrm{EB}$ method since it is time-consuming and costly and does not permit unequivocally to distinguish between apoptosis and necrosis. However this method seems to be more sensitive in early detection of apoptosis in cells that by morphological analysis with $\mathrm{AO} / \mathrm{EB}$ double staining for fluorescence microscopy were identified as viable. In TUNEL we observed that 3 sec-irradiation of HL60 cells resulted in an increased incorporation of fluorescein-labelled nucleotides in relation to the control. This may suggest that cells appearing microscopically viable may be in fact in a very early stage of apoptosis. This hypothesis may be tested performing measurement of cell death using longer periods of incubation post-irradiation, as 8 and $24 \mathrm{~h}$.

Annexin V assay is now widely used for detection of apoptosis induced by a variety of stimuli, is considered the most sensitive flow cytometric assay and when used simultaneously with a membrane impermeable DNA stain as propidium iodide enables discrimi- nation of the different stages of apoptosis, and necrotic cells $[25,49]$. This assay was also considered to be an early marker of apoptosis, occurring prior to the detection of DNA breaks, evaluated by TUNEL or ISNT (in situ nick translation) assays [27,34]. With annexin VFITC/PI assay it was possible to detect a higher percentage of early apoptotic cells and a smaller percentage of viable cells in all irradiation periods that induced apoptosis when compared to AO/EB double staining for flow cytometry. However in our model, chromatin condensation evaluated by $\mathrm{AO} / \mathrm{EB}$ in fluorescence microscopy, was detected in a higher percentage of cells than the translocation of phosphatidylserine monitored by annexin V-FITC/PI assay, what suggests that either the AO/EB technique (by fluorescence microscopy) is more sensitive or is able to detect apoptosis at an earlier step. This was also achieved by O'Brien et al. [34] in plant cells of Nicotiana plumbaginifolia, but in their model of apoptosis induction (camptothecin) annexin $\mathrm{V}$ was an earlier indicator than TUNEL assay. This method however is a rapid way to identify and discriminate apoptotic and necrotic cells.

In this study we pointed out advantages and disadvantages of the different methods tested in our model, but it is important to say that AO/EB double staining read in fluorescence microscopy seems to be the most reliable, cheap and flawless technique with the sole disadvantage of requiring immediate reading.

The choice of the most appropriate method of detection of cell death is not peaceful amongst the different groups studying apoptosis as the type of model used may be relevant as well as the need to quantify or just identify the type of cell death. Ours and many other studies suggest that the utilisation of two or more different techniques may be convenient to avoid determination errors.

\section{Acknowledgements}

This work was supported in part by the JNICT grant no. PBIC/C/SAU/1524/92 and PRAXIS XXI grant no. PSAU/C/SAU/68/96. Dr Marina Leite is the recipient of a Ph.D. fellowship no. PRAXIS XXI/BD/14659/97 granted by the Fundação da Ciência e Tecnologia. We thank Dr Jorge Candeias for his suggestions and allowing the use of the flow cytometry facilities at the Department of Immunology of Hospital S. João/Faculty of Medicine of Porto University, and Dr João Pedro Ramos for his helpful suggestions. 


\section{Abbreviations}

AO, acridine orange; bp, base pairs; BSA, bovine serum albumin; DTT, dithiothreitol; EA, early apoptotic cells; EB, ethidium bromide; EDTA, ethylenediaminotetraacetic acid; F-12-ddUTP, fluorescein-122'-dideoxyuridine-5'-triphosphate; FITC, fluorescein isothiocyanate; h, hour; LA, late apoptotic cells; min, minutes; N, necrotic cells; PBS, phosphate buffered saline; PI, propidium iodide; sec, seconds; TB, trypan blue; TdT, terminal deoxynucleotidyl transferase; TUNEL, terminal deoxynucleotidyltransferase dUTP nick-end labelling; UV, ultraviolet radiation; V, viable cells.

\section{References}

[1] J.C. Ameisen, Programmed cell death and AIDS: from hypothesis to experiment, Immunol. Today 13 (1992), 388-391.

[2] M.J. Arends, R.G. Morris and A.H. Wyllie, Apoptosis: the role of the endonuclease, Am. J. Pathol. 136 (1990), 593-608.

[3] J.L. Binet, F. Mentz and H. Merle-Beral, Apoptosis in blood diseases, Hematol. Cell Ther. 38 (1996), 253-264.

[4] R.S. Chapman, C.M. Chresta, A.A. Herberg, H.M. Beere, S. Heer, A.D. Whetton, J.A. Hickman and C. Dive, Further characterisation of the in situ terminal deoxynucleotidyl transferase (TdT) assay for the flow cytometric analysis of apoptosis in drug resistant and drug sensitive leukaemic cells, Cytometry 20 (1995), 245-256.

[5] J.J. Cohen, Programmed cell death in the immune system, $A d v$. Immunol. 50 (1991), 55-85.

[6] J.J. Cohen, Overview: mechanisms of apoptosis, Immunol. Today 14 (1993), 126-130.

[7] G.M. Cohen, X.-M. Sun, R.T. Snowden, D. Dinsdale and D.N. Skilleter, Key morphological features of apoptosis may occur in the absence of internucleosomal DNA fragmentation, Biochem. J. 286 (1992), 331-334.

[8] R.J. Collins, B.V. Harmon, G.C. Gobé and J.F.R. Kerr, Internucleosomal DNA cleavage should not be the sole criterion for identifying apoptosis, Int. J. Radiat. Biol. 61 (1992), 451-453.

[9] S. Collins, R.C. Gallo and R.E. Gallagher, Continuous growth and differentiation of human myeloid leukaemic cells in suspension culture, Nature 270 (1977), 347-349.

[10] T.G. Cotter, J.M. Glynn, F. Echeverri and D.R. Green, The induction of apoptosis by chemotherapeutic agents occurs in all phases of the cell cycle, Anticancer Res. 12 (1992), 773-780.

[11] Z. Darzynkiewicz, S. Bruno, G. Del Bino, W. Gorczyca, M.A. Hotz, P. Lassota and F. Traganos, Features of apoptotic cells measured by flow cytometry, Cytometry 13 (1992), 795808.

[12] C. Dive, C.D. Gregory, D.J. Phipps, D.L. Evans, A.E. Milner and A.H. Wyllie, Analysis and discrimination of necrosis and apoptosis (programmed cell death) by multiparameter flow cytometry, Biochim. Biophys. Acta 1133 (1992), 275-285.
[13] R.E. Ellis, J. Yuan and H.R. Horvitz, Mechanisms and functions of cell death, Annu. Rev. Cell Biol. 7 (1991), 663-698.

[14] V.A. Fadok, D.R. Voelker, P.A. Campbell, J.J. Cohen, D.L. Bratton and P.M. Henson, Exposure of phosphatidylserine on the surface of apoptotic lymphocytes triggers specific recognition and removal by macrophages, J. Immunol. 148 (1992), 2207-2216.

[15] L.J. Fairbairn, G.J. Cowling, B.M. Reipert and T.M. Dexter, Suppression of apoptosis allows differentiation and development of a multipotent hemopoietic cell line in the absence of added growth factors, Cell 74 (1993), 823-832.

[16] A. Fraser and G. Evan, A license to kill, Cell 85 (1996), 781784

[17] M.-L. Gougeon and L. Montagnier, Apoptosis in AIDS, Science 260 (1993), 1269-1270.

[18] W. Gorczyca, K. Bigman, A. Mittelman, T. Ahmed, J. Gong, M.R. Melamed and Z. Darzynkiewicz, Induction of DNA strand breaks associated with apoptosis during treatment of leukemias, Leukemia 7 (1993), 659-670.

[19] B. Grasl-Kraupp, B. Ruttkay-Nedecky, H. Koudelka, K. Burowska, W. Bursch and R. Schulte-Hermann, In situ detection of fragmented DNA (TUNEL assay) fails to discriminate among apoptosis, necrosis, and autolytic cell death: a cautionary note, Hepatology 21 (1995), 1465-1468.

[20] Y. Gravieli, Y. Sherman and S.A. Ben-Sasson, Identification of programmed cell death in situ via specific labeling of nuclear DNA fragmentation, J. Cell Biol. 119 (1992), 493-501.

[21] J.A. Hickman, Apoptosis and chemotherapy resistence, Eur. J. Cancer 32A (1996), 921-926.

[22] J.F.R. Kerr, Shrinkage necrosis: a distinct mode of cellular death, J. Path. 105 (1971), 13-20.

[23] J.F.R. Kerr, A.H. Wyllie and A.R. Currie, Apoptosis: a base biological process phenomenon wide-ranging implications in tissue kinetics, Br. J. Cancer 26 (1972), 239-257.

[24] J.F.R. Kerr, C.M. Winterford and B.V. Harmon, Apoptosis: its significance in cancer and cancer therapy, Cancer 73 (1994), 2013-2026.

[25] G. Koopman, C.P. Reutelingsperger, G.A. Kuijten, R.M. Keehnen, S.T. Pals and M.H. van Oers, Annexin V for flow cytometric detection of phosphatidylserine expression on B cells undergoing apoptosis, Blood 84 (1994), 1415-1420.

[26] S.C. Lane, R.D. Jolly, D.E. Schmechel, J. Alroy and R.M. Boustany, Apoptosis as the mechanism of neurodegeneration in Batten's disease, J. Neurochem. 67 (1996), 677-683.

[27] H. Lecoeur, E. Ledru, M.-C. Prévost and M.-L. Gougeon, Strategies for phenotyping apoptotic peripheral human lymphocytes comparing ISNT, annexin-V and 7-AAD cytofluorometric staining methods, J. Immunol. Methods 209 (1997), 111-123.

[28] S.V. Lennon, S.J. Martin and T.G. Cotter, Dose-dependent induction of apoptosis in human tumour cell lines by widely diverging stimuli, Cell Prolif. 24 (1991), 203-214.

[29] T.J. Liegler, W. Hyun, T.S.B. Yen and D.P. Stites, Detection and quantification of live, apoptotic, and necrotic human peripheral lymphocytes by single-laser flow cytometry, Clin. Diagn. Lab. Immunol. 2 (1995), 369-376.

[30] S.J. Martin and T.G. Cotter, Ultraviolet B irradiation of human leukaemia HL60 cells in vitro induces apoptosis, Int. J. Radiat. Biol. 59 (1991), 1001-1016. 
[31] S.J. Martin, P.M. Matear and A. Vyakarnam, HIV infection of human $\mathrm{CD}^{+} \mathrm{T}$ cells in vitro. Differential induction of apoptosis in these cells, J. Immunol. 152 (1994), 330-342.

[32] A.J. McGahon, S.J. Martin, R.P. Bissonnette, A. Mahboubi, Y. Shi, R.J. Mogil, W.K. Nishioka and D.R. Green, The end of the (cell) line: methods for the study of apoptosis in vitro, in: Cell Death, L.M. Schwartz and B.A. Osborne, eds, Academic Press, Inc., CA, 1995, p. 153.

[33] F. Oberhammer, J.W. Wilson, C. Dive, I.D. Morris, J.A. Hickman, A.E. Wakeling, P.R. Walker and M. Sikorska, Apoptotic death in epithelial cells: cleavage of DNA to 300 and/or $50 \mathrm{~Kb}$ fragments prior to or in absence of internucleosomal fragmentation, EMBO J. 12 (1993), 3679-3684.

[34] I.E.W. O'Brien, C.P.M. Reutelingsperger and K.M. Holdaway, Annexin-V and TUNEL use in monitoring the progression of apoptosis in plants, Cytometry 29 (1997), 28-33.

[35] B.A. Osborne, Induction of genes during apoptosis: examples from the immune system, Semin. Cancer Biol. 6 (1995), 27-33.

[36] B. Piqueras, B. Autran, P. Debre and G. Gorochov, Detection of apoptosis at single-cell level by direct incorporation of fluorescein-dUTP in DNA strand breaks, BioTechniques $\mathbf{2 0}$ (1996), 634-640.

[37] C. Portera-Cailliau, J.C. Hedreen, D.L. Price and V.E. Koliatsos, Evidence for apoptotic cell death in Huntington disease and excitotoxic animal models, J. Neurosci. 15 (1995), 17753787.

[38] G. Prindull, Apoptosis in the embryo and tumorigenesis. Eur. J. Cancer 31A (1995), 116-123.

[39] M.C. Raff, B.A. Barnes, J.F. Burne, H.S. Coles, Y. Ishizaki and M.D. Jacobson, Programmed cell death and the control of cell survival: lessons from the nervous system, Science 262 (1993), 695-700.

[40] S. Rowan and D.E. Fisher, Mechanisms of apoptotic cell death, Leukemia 11 (1997), 457-465.

[41] L. Sachs and J. Lotem, Control of programmed cell death in normal and leukemic cells: new implications for therapy, Blood 82 (1993), 15-21.

[42] J.W. Saunders, Death in embryonic systems, Science 154 (1966), 604-612.

[43] G. Smale, N.R. Nichols, D.R. Brady, C.E. Finch and W.E. Horton, Jr., Evidence fpr apoptotic cell death in Alzheimer's disease. Exp. Neurol. 133 (1995), 225-230.
[44] C.A. Smith, G.T. Williams, R. Kingston, E.J. Jenkinson and J.J.T. Owen, Antibodies to CD3/T-cell receptor complex induce death by apoptosis in immature T cells in thymic cultures, $\mathrm{Na}$ ture 337 (1989), 181-184.

[45] S.W. Sherwood and R.T. Schimke, Cell cycle analysis of apoptosis using flow cytometry, in: Cell Death, L.M. Schwartz and B.A. Osborne, eds, Academic Press, Inc., CA, 1995, p. 77.

[46] W.G. Telford, L.E. King and P.J. Fraker, Evaluation of glucocorticoid-induced DNA fragmentation in mouse thymocytes by flow cytometry, Cell Prolif. 24 (1991), 447-459.

[47] W.G. Telford, L.E. King and P.J. Fraker, Comparative evaluation of several DNA binding dyes in the detection of apoptosisassociated chromatin degradation by flow cytometry, Cytometry 13 (1992), 137-143.

[48] C.B. Thompson, Apoptosis in the pathogenesis and treatment of disease, Science 267 (1995), 1456-1462.

[49] I. Vermes, C. Haanen, H. Steffens-Nakken and C. Reutelingsperger, A novel assay for apoptosis. Flow cytometric detection of phosphatidylserine expression on early apoptotic cells using fluorescein labelled annexin V, J. Immunol. Methods $\mathbf{1 8 4}$ (1995), 39-51.

[50] B. Verhoven, R.A. Schlegel and P. Williamson, Mechanisms of phosphatidylserine exposure, a phagocyte recognition signal, on apoptotic T lymphocytes, J. Exp. Med. 182 (1995), 15971601.

[51] G.T. Williams, Apoptosis in the immune system, J. Path. $\mathbf{1 7 3}$ (1994), $1-4$.

[52] G.T. Williams and C.A. Smith, Molecular regulation of apoptosis: genetic controls on cell death, Cell 74 (1993), 777-779.

[53] G.T. Williams, C.A. Smith, E. Spooncer, T.M. Dexter and D.R. Taylor, Haemopoietic colony stimulating factors promote cell survive by suppressing apoptosis, Nature 343 (1990), 7679.

[54] A.H. Wyllie, Glucocorticoid-induced thymocyte apoptosis is associated with endogenous endonuclease activation, Nature 284 (1980), 555-556.

[55] A.H. Wyllie, J.F.R. Kerr and A.R. Currie, Cell death: the significance of apoptosis, Int. Rev. Cytol. 68 (1980), 251-306.

[56] Y. Yoshida, Hypothesis: apoptosis may be the mechanism responsible for the premature intramedullary cell death in the myelodysplastic syndrome, Leukemia 7 (1993), 144-146. 


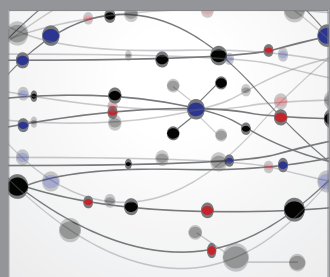

The Scientific World Journal
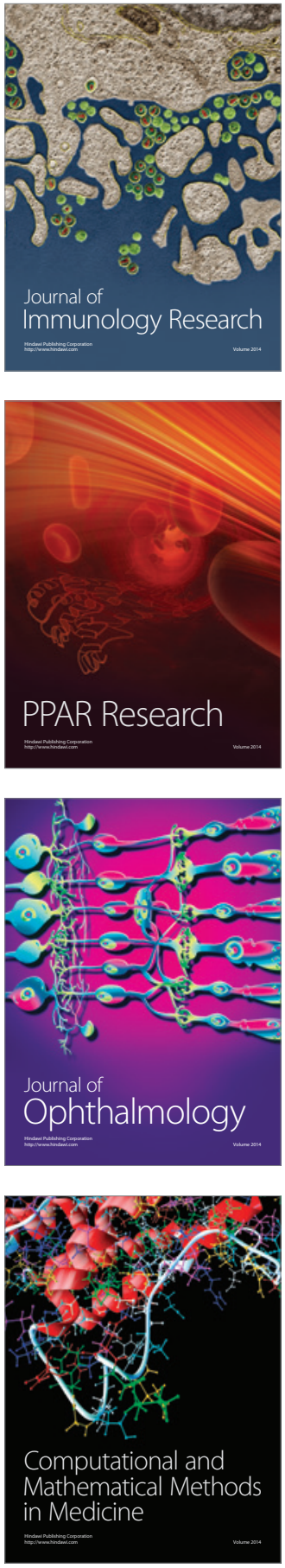

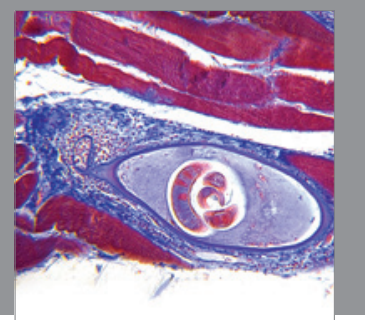

Gastroenterology

Research and Practice
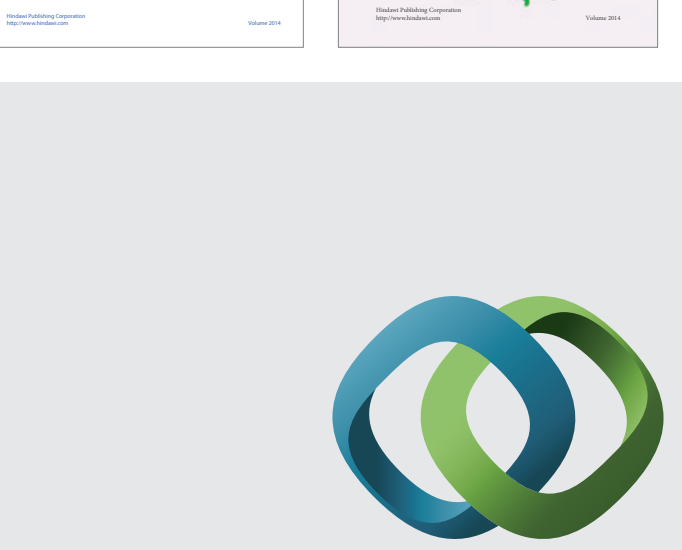

\section{Hindawi}

Submit your manuscripts at

http://www.hindawi.com
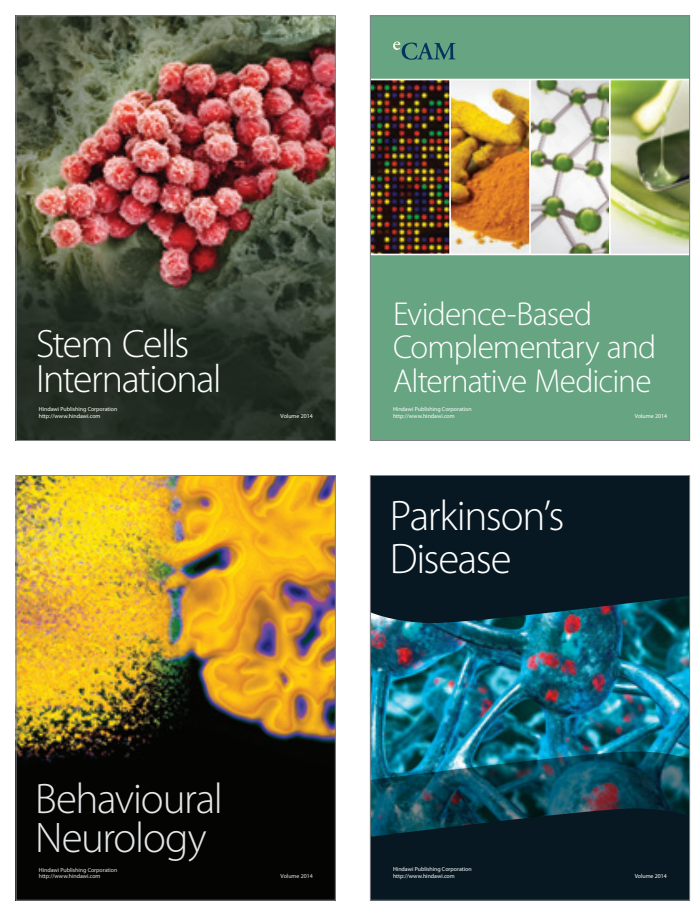

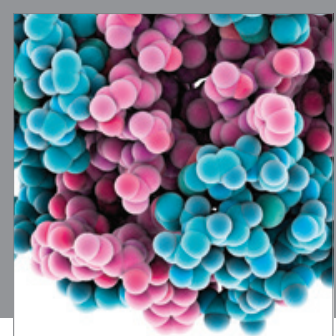

Journal of
Diabetes Research

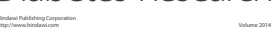

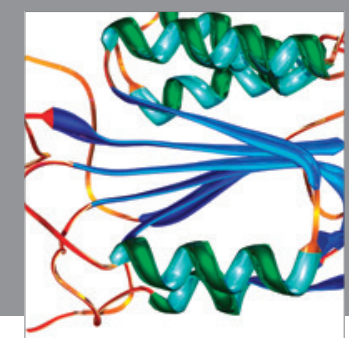

Disease Markers
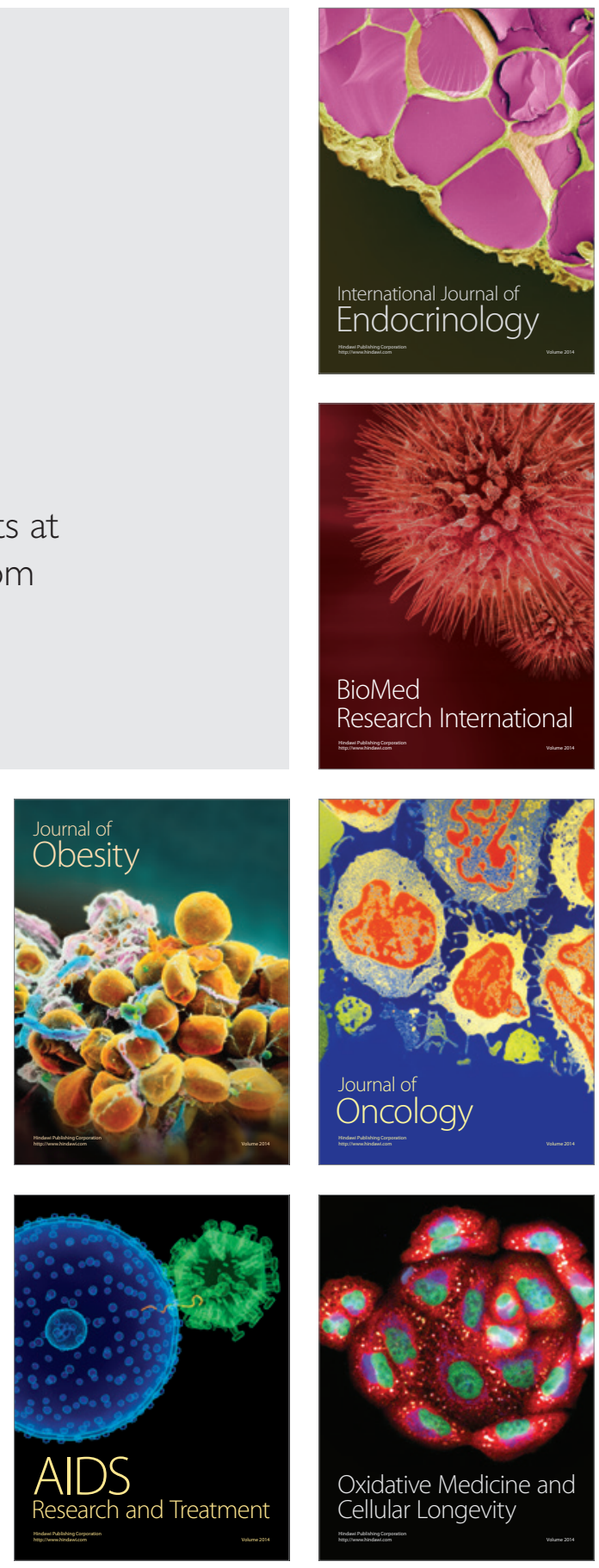